ISSN: 2146-0574, eISSN: 2536-4618

Kimya / Chemistry

DOI: $10.21597 /$ jist.779169

Araştırma Makalesi / Research Article

Geliş tarihi / Received: 11-08-2020

Kabul tarihi / Accepted: 24-11-2020

\title{
Environmentally Friendly Rapid Synthesis of Gold Nanoparticles from Artemisia absinthium Plant Extract and Application of Antimicrobial Activities
}

\section{Mehmet Firat BARAN ${ }^{1}$, Cumali KESKIN ${ }^{1 *}$, Mehmet Nuri ATALAR ${ }^{2}$, Ayşe BARAN $^{3}$}

\begin{abstract}
Nanoparticles are used in many areas due to their superior properties. Recently, producing these particles using environmentally friendly synthesis methods has become very popular. Within this context, in this study, gold nanoparticles (AuNPs) were synthesized by using a quick, ecofriendly method with the green leaf extract of Artemisia absinthium (wormwood). The grain size of the AuNPs was determined as $13.40 \mathrm{~nm}$ according to the Debye-Scherrer equation. The inhibitory effects of the AuNPs on the growth of the tested microorganisms were determined by the minimum inhibitory concentration (MIC) method. The MIC is described as the minimum concentration of an antimicrobial agent that inhibits the growth of a microorganism. The obtained AuNPs were showed inhibitory effects on $S$. aureus, $S$. pyogenes, E. coli, $P$. aeruginosa strains and $C$. albicans yeast at concentrations of $0.250,0.125,0.125,0.033$ and $0.66 \mathrm{mg} \mathrm{mL}^{-1}$ respectively.
\end{abstract}

Keywords: Antimicrobial, gold nanoparticles, green synthesis, SEM-EDX, TGA, XRD

\section{Artemisia absinthium Bitki Ekstraktından Altın Nanopartiküllerin Çevre Dostu Hızlı Sentezi ve Antimikrobiyal Aktivitelerin Uygulanması}

ÖZET: Nanopartiküller, üstün özelliklerinden dolayı birçok alanda kullanılmaktadır. Son zamanlarda, bu parçacıkların çevre dostu sentez yöntemleri kullanılarak üretilmesi çok popüler hale gelmiştir. $\mathrm{Bu}$ bağlamda, bu çalışmada, altın nanopartiküller (AuNP'ler), Artemisia absinthium'un (pelin otu) yeşil yaprak özütü ile hızlı ve çevre dostu bir yöntem kullanılarak sentezlenmiştir. AuNP'lerin tane boyutu Debye-Scherrer denklemine göre $13.40 \mathrm{~nm}$ olarak belirlendi. AuNP'lerin test edilen mikroorganizmaların büyümesi üzerindeki inhibe edici etkileri, minimum inhibe edici konsantrasyon (MİC) yöntemi ile belirlenmiştir. MİC, bir mikroorganizmanın büyümesini engelleyen bir antimikrobiyal maddenin minimum konsantrasyonu olarak tanımlanmaktadır. Elde edilen AuNP'ler, sirasiyla $0.250,0.125,0.125,0.033$ ve $0.66 \mathrm{mg} \mathrm{mL}^{-1}$ konsantrasyonlarında $S$. aureus, $S$. pyogenes, $E$. coli, $P$. aeruginosa suşları ve $C$. albicans mayası üzerinde önleyici etkiler göstermiştir.

Anahtar Kelimeler: Antimikrobiyal, altın nanopartiküller, yeşil sentez, SEM-EDX, TGA, XRD

\footnotetext{
${ }^{1}$ Mehmet Firat BARAN (Orcid ID: 0000-0001-8133-6670), Cumali KESKIN ${ }^{*}$ (Orcid ID: 0000-0003-37580654), Mardin Artuklu University, Department of Medical Services and Techniques, Mardin, Turkey

${ }^{2}$ Mehmet Nuri ATALAR (Orcid ID: 0000-0003-2993-2605), Iğdır University, Department of Biochemistry, Faculty of Arts and Science, Iğdır, Turkey

${ }^{3}$ Ayşe BARAN (Orcid ID: 0000-0002-2317-0489), Mardin Artuklu University, Institute of Science, Mardin, Turkey

*Sorumlu Yazar/Corresponding Author: Cumali KESKİN, e-mail: ckeskinoo@gmail.com
} 


\section{INTRODUCTION}

Metal nanoparticles have superior chemical and physical properties (Huang and Yang, 2004). Due to these properties, they are widely used in many sectors such as the food, cosmetics, textile, optics and electronics, healthcare and biomedical (Khan et al., 2017; Chaudhry, 2018; Shao et al., 2018; Shaid et al.,2018; Santhosh et al., 2019; Shahid et al., 2019; Khan et al., 2020). Metal nanoparticles can be procured by using physical, chemical and biological methods. However, there are various disadvantages to using the physical and chemical methods such as the fact that they contain toxic chemicals in the synthesis stage, require high energy and are costly (Gunalan et al., 2012; Kumar et al., 2018; Kanchi et al., 2018; Jeyaraj et al., 2019). Thus, biological methods are more attractive compared to these two methods. Plants, bacteria, fungi and algae can be used in the biological synthesize of AuNPs (Dubey et al., 2010; Rajathi et al., 2014). The interest in plant-based synthesis methods increases by day because they are easy to operate and eco-friendly. Vegetable sources such as seeds, leaves, and fruit can be used as a source in AuNPs synthesis (Mythili et al., 2018). The phytochemicals in plant extracts produce AuNPs by reducing the gold metal salt in aqueous solutions (Aravinthan et al., 2016; Teimuri-mofrad et al., 2017).

AuNPs have led to significant improvements in biology and medicine (Ankamwar et al., 2010; Giljohann et al., 2010). Gold nanoparticles (AuNPs) are used in catalysis, anti-cancer agents, agriculture, the pharmaceutical industry, anti-microbial and anti-oxidant agents and many bacteria, algae, and fungi (Philip, 2010; Kumar et al., 2013; Rajathi et al., 2014; Balalakshmi et al., 2017; Menon et al., 2017; Kobashigawa et al., 2018). AuNPs are biocompatible and their unique surface plasmon resonance (SPR) peaks are important for biomedical uses (Patra et al., 2016; Murphin Kumar et al., 2017). Zingiber officinale (Menon et al., 2017), Butea monosperma (Balalakshmi et al., 2017), Terminalia catappa (Philip, 2010), Mentha piperita (Kumar et al., 2013), Alcea rosea (Khoshnamvand et al., 2019) just as, green synthesis of AuNPs was carried out from plant sources.

In this study, AuNPs were synthesized with the plant extract of Artemisia absinthium (Wormwood herb) by using an environmentally friendly, easy and cost-effective method and their effects on the reproduction of pathogenic microorganisms were investigated. The syntheses of the NPs with different experimental methods are schematized in Figure 1.

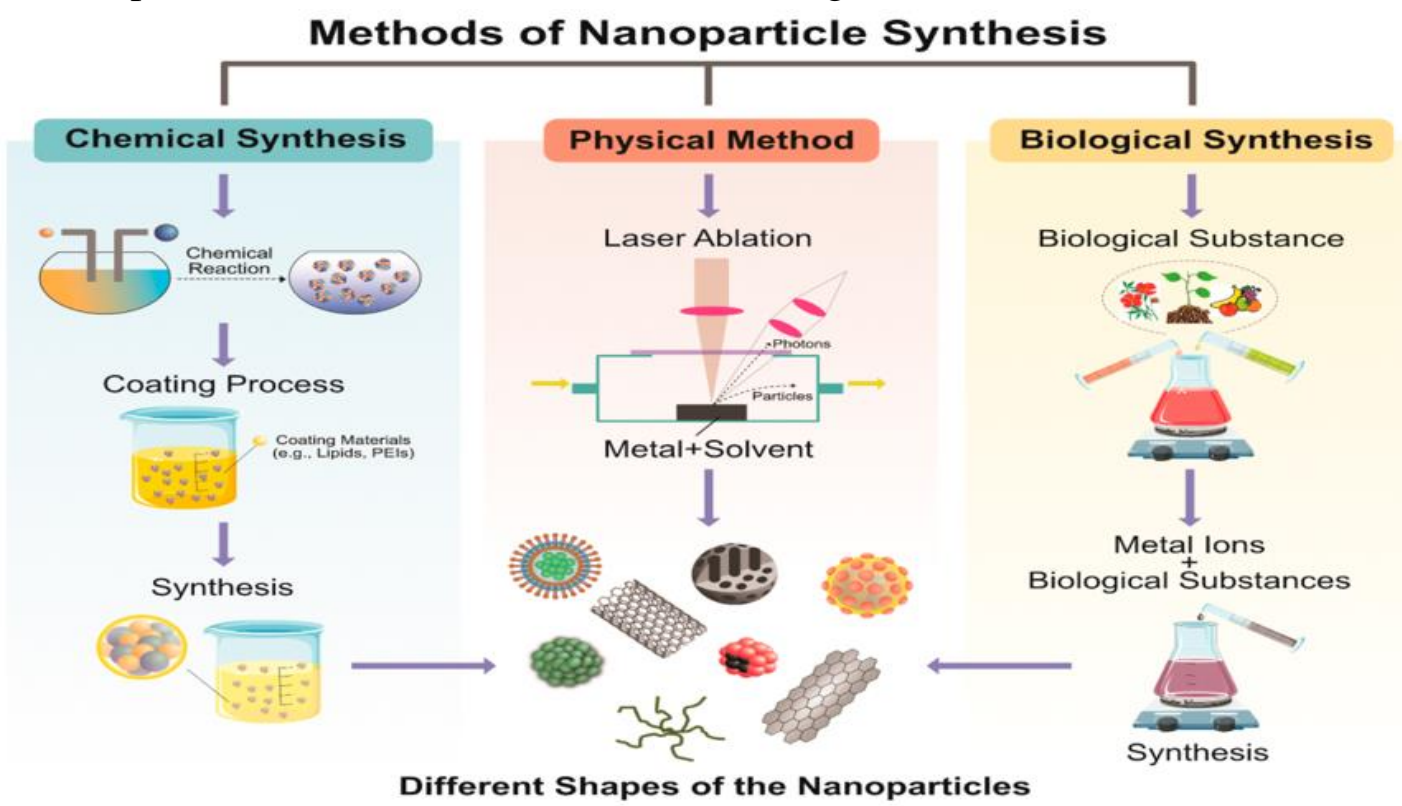

Figure 1. Schematic view of the commonly used nanoparticle synthesis methods (Jeyaraj et al., 2019) 


\section{MATERIALS AND METHODS}

\section{Materials}

\section{Preparation of the Wormwood Herb extract and gold tetrachloride ( $\left.\mathrm{HAuCI}_{4} .3 \mathrm{H}_{2} \mathrm{O}\right)$ solution}

The plant samples were collected in the Savur district of the province of Mardin during the summer. The samples were initially washed with tap water and then washed several times using distilled water. The leaves of the plant samples were left to dry for 48 hours in room conditions. A total of $50 \mathrm{~g}$ of the dried plant leaves were placed into a $500 \mathrm{ml}$ beaker, then $250 \mathrm{ml}$ of distilled water was added and the mixture was boiled. To create the desired reaction, the mixture was boiled for 5 minutes. The extract was then left to cool in room temperature. Filtering was carried out with coarse filter paper and Whatman filter paper No. 1. The obtained extract was stored at $+4{ }^{\circ} \mathrm{C}$ until the experiments were conducted. A 1 millimolar $(\mathrm{mM})$ gold solution was produced for use in synthesis from the gold tetrachloride $\left(\mathrm{HAuCI}_{4} .3 \mathrm{H}_{2} \mathrm{O}\right)$ of $49.0 \%$ purity, which was commercially purchased from Sigma-Aldrich. The Synthesis and experiment steps of the AuNPs are schematized in Figure 2.

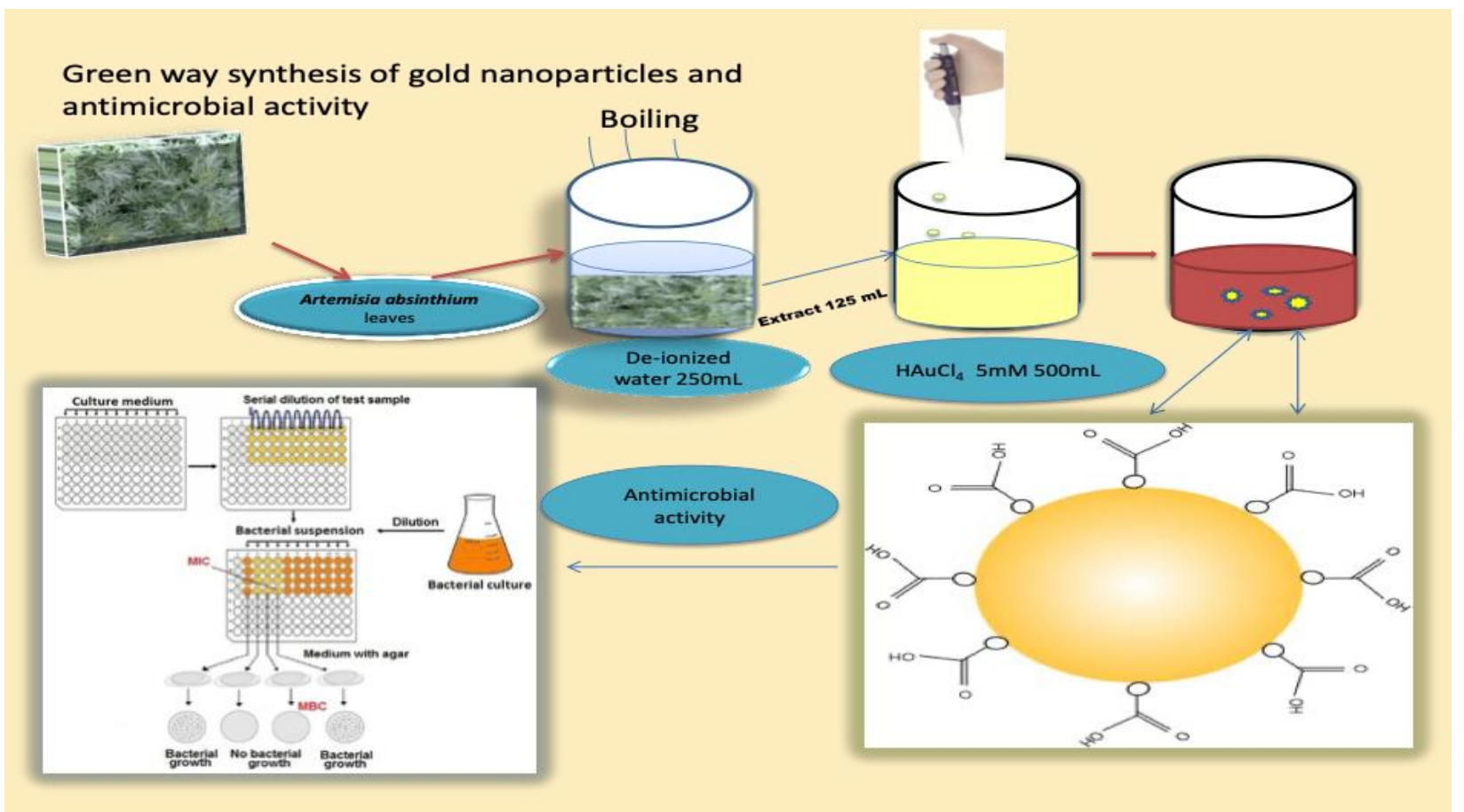

Figure 2. Schematic view of the synthesis of AuNPs with wormwood herb leaves extract.

\section{Biosynthesis}

Exactly $50 \mathrm{ml}$ of the extract prepared from the leaves of the Wormwood herb and $250 \mathrm{ml}$ of $\mathrm{HAuCI}_{4}$ solution were placed in a $1000 \mathrm{ml}$ flask and left to react at $45{ }^{\circ} \mathrm{C}$ after being simply shaken by hand. The reaction mixture was found to change color in accordance with time. The liquid content obtained as a result of the reaction was centrifuged with an OHAUS FC 5706 device at $6.000 \mathrm{rpm}$ for 15 minutes. After being washed several times, the precipitated solid was left to dry in an oven at $75{ }^{\circ} \mathrm{C}$ for 24 hours. The obtained particles were then prepared for characterization.

The phytochemicals in plant extracts reduce $\mathrm{Au}^{+3}$ to $\mathrm{Au}^{0}$ and, thus, form AuNPs (Patra et al., 2016; Murphin Kumar et al., 2017). Such extracts are both reducing and stabilizing (Giljohann et al., 2010). 


\section{Characterization}

\section{UV-visible spectroscopy}

The absorbance values depending on physical color change $(0,5,10,20,30,40,50,60,90,120$ and 180 minutes) were examined by using an Agilent Cary 60 UV-visible (UV-vis) spectrophotometer. UV-vis spectroscopy was used to observed the surface plasmon resonance (SPR) bands of the biosynthesized AuNPs. Thus, the formation and presence of the AuNPs were evaluated.

\section{Fourier transform infrared spectroscopy}

To evaluating the phytochemicals and functional groups responsible for synthesis (reduction reaction) in wormwood leaf extract used, the measurement was performed with Fourier transform infrared (FT-IR) spectroscopy (Perkin Elmer Spectrum One instrument).

\section{Energy dispersive X-ray spectrum and scanning electron microscopy}

The morphological images and element composition of the particles were evaluated with EVO 40 LEQ scanning electron microscopy (SEM) - energy dispersive X-Ray spectroscopy (EDX) device.

\section{X-ray diffraction}

The crystal structure of the particles was evaluated by a RadB-DMAX II computer-controlled Xray diffractometer analysis, while the crystal particle size was calculated using the Debye-Scherer equation (Jeyaraj et al., 2019).

\section{Thermal gravimetric analysis}

Using a Shimadzu TGA-50 device, the degradation data of the AuNPs between $25-1000{ }^{\circ} \mathrm{C}$ and the thermogravimetric analysis (TGA) of the particles with a flow rate of $20 \mathrm{~mL} / \mathrm{min}$ in the atmosphere of $\mathrm{N}_{2}(\mathrm{~g})$ with a heating rate of $10{ }^{\circ} \mathrm{C} / \mathrm{min}$, and their durability were checked after heat treatment.

\section{Preparation of the Broth and Microorganism Suspensions for Antimicrobial Activity}

Investigations were performed to determine the suppressing effects of the AuNPs on the growth of micro-organisms by the microdilution method to determine the minimum inhibitory concentration (MIC). Microorganism suspensions were prepared according to the 0.5 McFarland (McFarland, 1907; Gholami-Shabani et al., 2015) concentration with Gram-negative Escherichia coli ATCC 25922, Pseudomonas aeruginosa ATCC 27853, gram-positive Staphylococcus aureus ATCC 29213, Streptococcus pyogenes ATTC 19615 bacteria and Candida albicans ATTC 10231 yeast.

A Muller Hinton liquid medium was used for the bacteria, while an RPMI medium was used for C. albicans. Media, nanoparticle and microorganism suspensions were added to the microplates and the inoculated cultures were incubated at $37{ }^{\circ} \mathrm{C}$ for $24 \mathrm{~h}$. The antimicrobial effects of the commercially available colistin, fluconazole, vancomycin antibiotics and $1 \mathrm{mM}$ gold solution were also examined for comparison.

\section{RESULTS AND DISCUSSION}

\section{UV-visible spectroscopy analysis}

After the extract of the wormwood herb and $1 \mathrm{mM} \mathrm{HAuCl}_{4}$ (gold solution) were mixed the color change was observed. Measurements were taken at different time intervals, namely, 0, 5, 10, 20, 30, 40, 50, 60, 90,120 and 180 minutes, using a UV-vis spectroscopy and the color was found to change from light yellow to dark pink-red with the formation of vibrations on the SPR (Dubey et al., 2010) due to reduction (Figure 3). In a study, in which the synthesis of AuNPs was performed using the extract of the Salvia officinalis plant, it was determined that the color change from yellow to dark pink 
was linked to the formation of the AuNPs (Mythili et al., 2018). A similar conclusion was also made in a study in which the biological synthesis of AuNPs was carried out with the leaf extract of Ziziphus zizyphus (Aravinthan et al., 2016). When the UV-vis spectra of the present study were examined, it was determined that the maximum absorbance value at $528 \mathrm{~nm}$ indicated the formation and presence of the AuNPs. In a biosynthesis study conducted with the leaf extract of Satureja hortensis, the absorbances of AuNPs at a maximum wavelength of $528 \mathrm{~nm}$ were found (Teimuri-mofrad et al., 2017). Absorbance band values in the range of 500-600 nm indicate the presence of AuNPs (Mubarakali et al., 2011). In a different synthesis study performed using the extract of the Marsdenia tenacissima plant, the absorbance peaks between 525-540 nm were linked to the formation of AuNPs (Khoshnamvand et al., 2019).
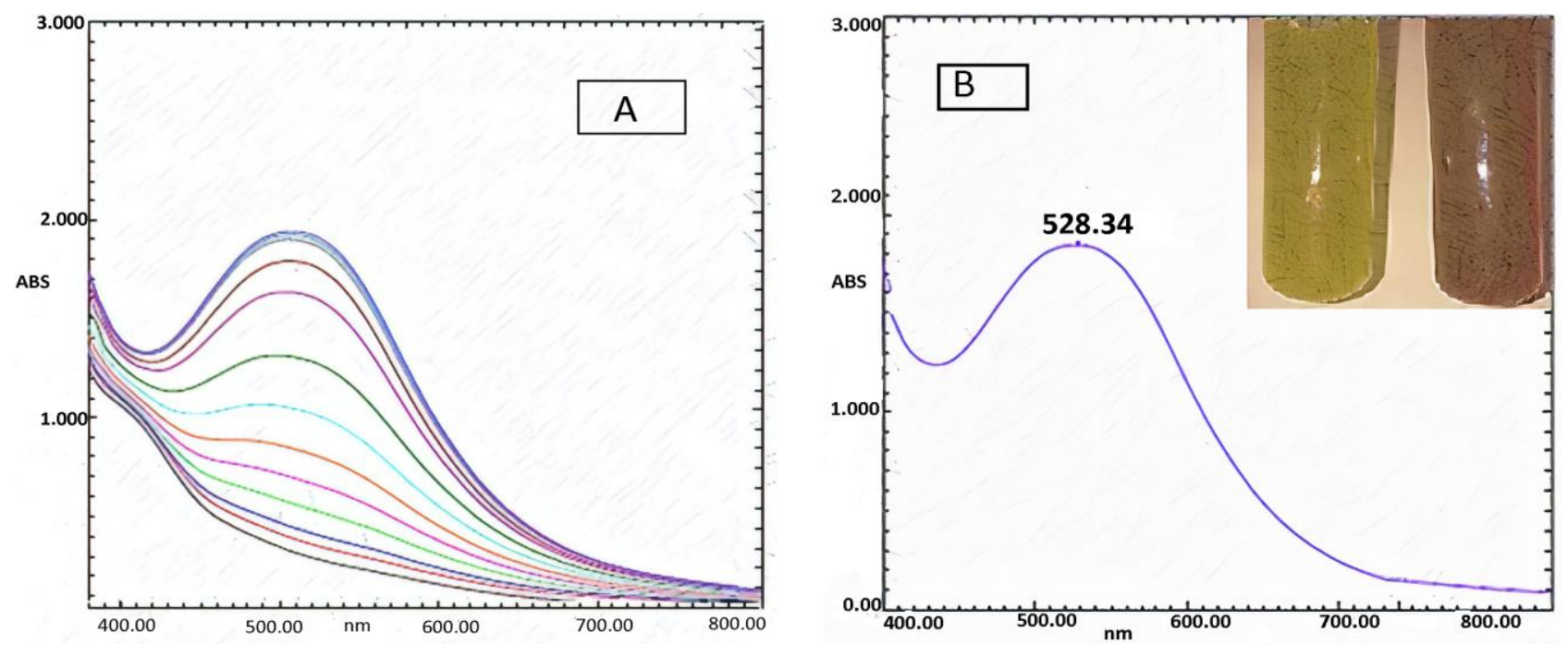

Figure 3 A. Result of UV -Vis spectroscopy analysis at the time-dependent formation of AuNPs. B. Maximum absorbance value of AuNPs by using UV-Vis Spectrophotometer

\section{Fourier transform infrared spectroscopy (FTIR)}

Fourier transform infrared (FT-IR) spectroscopy was used to characterize the functional groups responsible for the reduction of the phytochemicals in the Wormwood herb extract, which was used for synthesis. It can be said that the changes in the functional groups after the reduction in the FT-IR spectra were responsible for the formation of AuNPs by taking an active role in the reduction of the phytochemicals in the extract (Figure 4). When the functional groups that took part in the reduction during the formation of AuNPs were examined, it was observed that the peak between 3325.68$3324.10 \mathrm{~cm}^{-1}$ caused $-\mathrm{OH}$ stretching, the peak between $1636.31-1634.82 \mathrm{~cm}^{-1}$ caused $-\mathrm{C}=\mathrm{O}$ I amide band and the peak at $2360 \mathrm{~cm}^{-1}$ caused aldehyde related $-\mathrm{CH}$ stretching. After the extract and metal salt interaction, it was determined that these groups may be responsible for the reduction of the $1-2 \mathrm{~cm}^{-1}$ change in the $-\mathrm{OH}$ and $-\mathrm{C}=\mathrm{O}$ groups, respectively (Figure 4). Aldehyde groups are considered to be one of the functional groups responsible for the reduction in synthesis (Khoshnamvand et al., 2019). In herbal synthesis studies that supported the data of the present study, it was reported that the $\mathrm{NH}$ and/or $\mathrm{OH},(\mathrm{C}=\mathrm{O}) \mathrm{NH}_{2}$ groups were found to be responsible for reduction (Dwivedi et al., 2010; Kumar et al., 2013). 

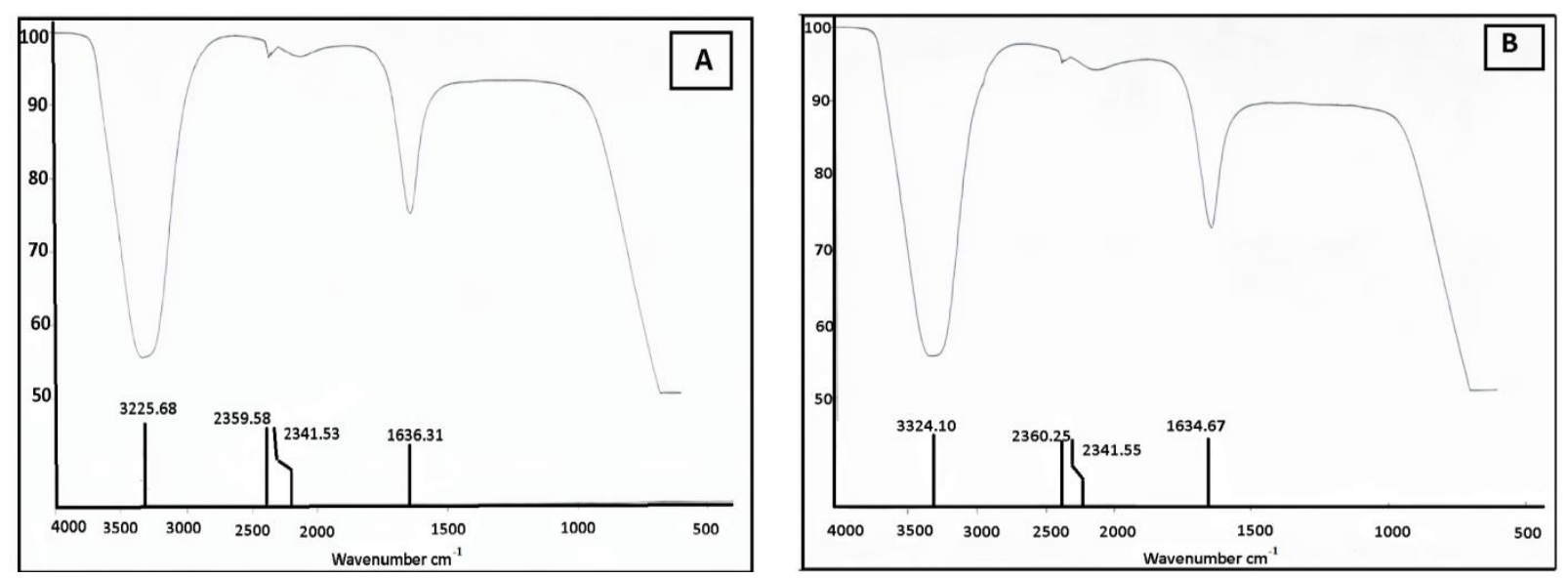

Figure 4 A. FTIR Analysis of obtained extract from the leaf of Wormwood herb B. Changes of existing functional groups in Wormwood herb after synthesis.

\section{Energy dispersive $X$-ray spectrum and scanning electron microscopy analyses}

Based on the EDX data, the element composition was found to be comprised mainly of gold. Other peaks were caused by pollution from the Wormwood herb extract (Figure 5). Similar results were obtained in synthesis studies conducted with Cymbopogon citratus and Pistia stratiotes extracts using an environmentally friendly method as the peaks corresponding to the gold in the composition of AuNPs were determined (Anuradha et al., 2015; Murugan et al., 2015). According to the SEM images, the AuNPs exhibited spherical and rectangular morphology below $100 \mathrm{~nm}$. In a synthesis study conducted with Cinnamomum camphora extract, AuNPs were found to exhibit spherical appearance between 55-80 nm (Oueslati et al., 2020). AuNPs synthesized with Trianthema decandra L. and Andrographis peniculata extracts were reported to exhibit spherical morphology between 37-79 and $56 \pm 12 \mathrm{~nm}$, respectively (Aljabali et al., 2018).
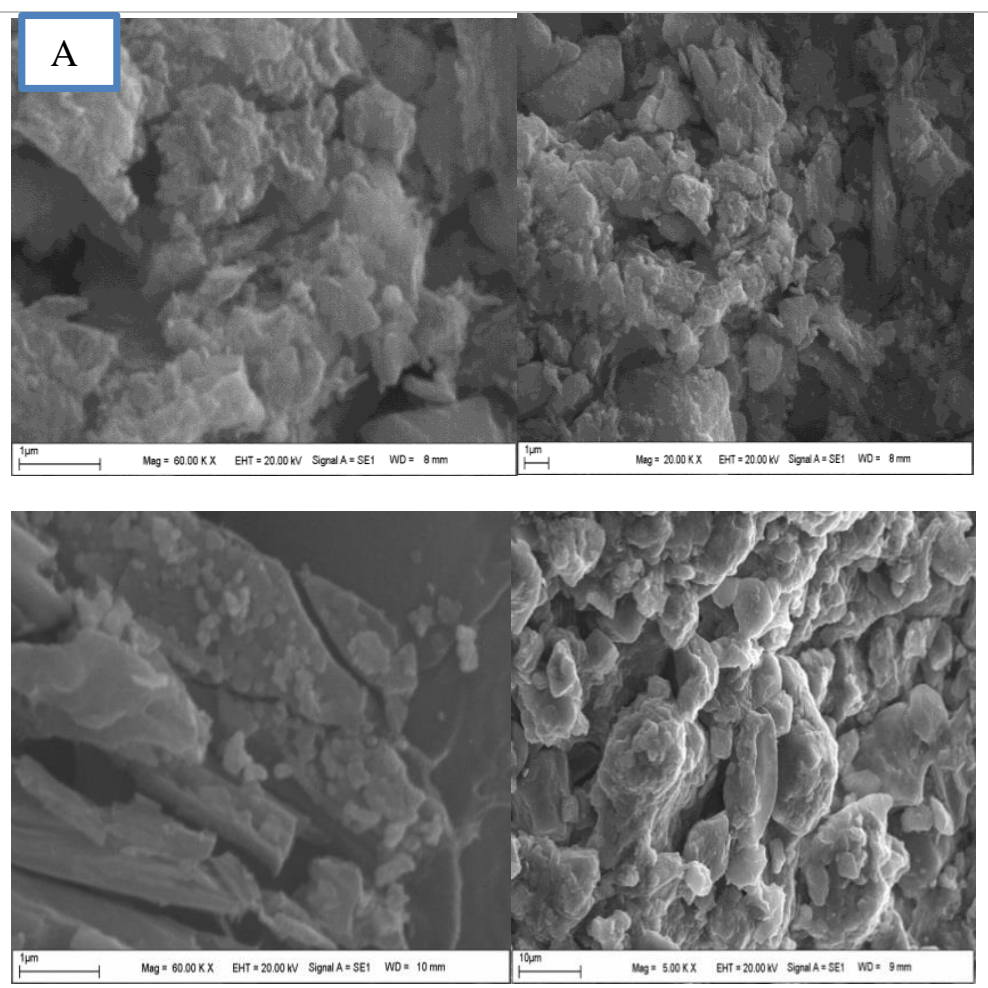

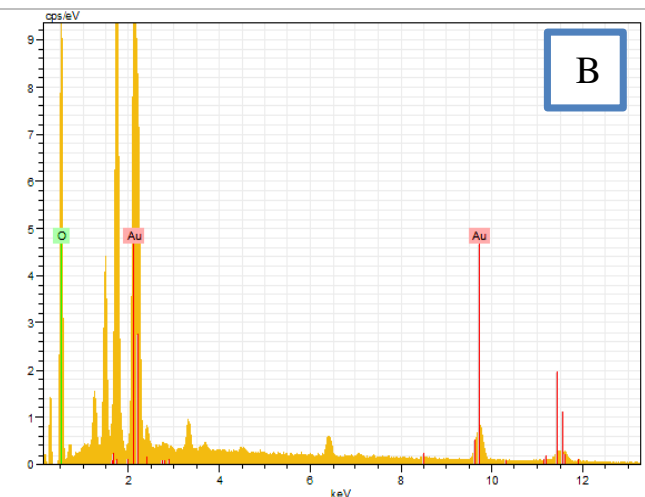

Spectrum: Objects 4

El AN Series unn. C norm. C Atom. C Error

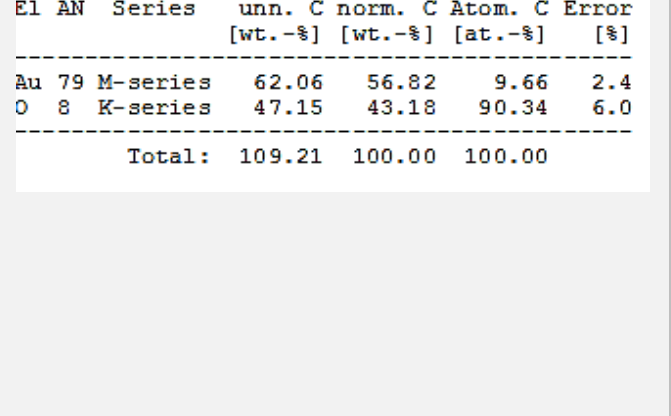

B. EDX profile of AuNPs.

Figure 5 A. SEM results of AuNPs 


\section{X-ray diffraction analysis data}

When X-ray diffraction (XRD) analysis data was examined (Figure 6), it was determined that the peaks at $111^{\circ}, 200^{\circ}, 220^{\circ}$ and $311^{\circ}$ corresponding to $2 \theta$ showed the cubic crystal structure of AuNPs. The numerical values corresponding to these peaks were 38.053, 44.24, 66.99 and 77.71 respectively. In the synthesis with the extracts of the Satureja hortens (Gharehyakheh et al., 2020), Marsdenia tenacissima inhibits (Sun et al., 2019) and Ginkgo biloba (Zha et al., 2017) plants the crystal structures of AuNPs were found at $111^{\circ}, 200^{\circ}, 220^{\circ}$ and $311^{\circ}$ peaks. The crystal size of the AuNPs calculated according to the Debye-Scherrer equation (Jacob et al., 2015; Jeyaraj et al., 2019) was determined as $13.40 \mathrm{~nm}$.

$\mathrm{D}=\mathrm{K} \lambda /(\beta \cos \theta)$

$\mathrm{D}=$ size of the particle $(\mathrm{nm})$,

$\mathrm{K}=$ Constant (0.89),

$\lambda=$ Wavelength X-ray (1.5406 $\AA)$,

$\beta=$ Half the value of the highest peak in radians $(\mathrm{FWHM}=1.267)$ and

$2 \theta=$ specified as the angle of refraction (38.053)

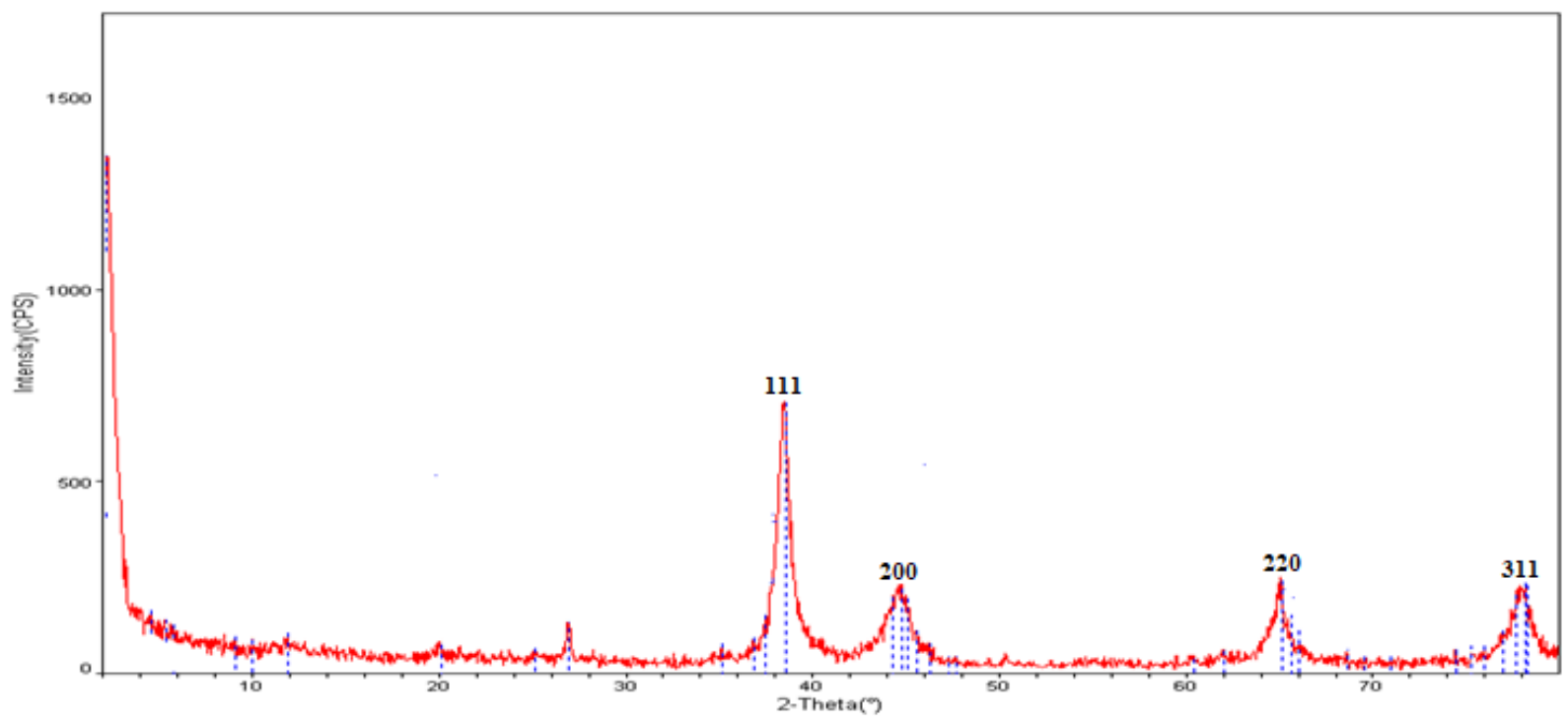

Figure 6. Diagram of XRD and phase analysis of AuNPs.

\section{Thermal gravimetric analysis data}

According to the results of the thermal gravimetric analysis - differential thermal analysis (TGADTA) (Figure 7), it can be seen from the curve that a $4.68 \%$ mass loss at $75.1-224.5{ }^{\circ} \mathrm{C}$ was caused by moisture and an $18.35 \%$ mass loss at $225-540{ }^{\circ} \mathrm{C}$ consisted of organic structures present in the plant extract. The mass loss of $3.26 \%$ mass at $-1000{ }^{\circ} \mathrm{C}$ showed that the nanomaterial was slowly degrading. These results showed that the particles obtained were stable even at high temperatures. The TGA-DTA data of another study, in which nanoparticles were obtained using an eco-friendly method, were interpreted in a similar way to the present study (Gharehyakheh et al., 2020). 

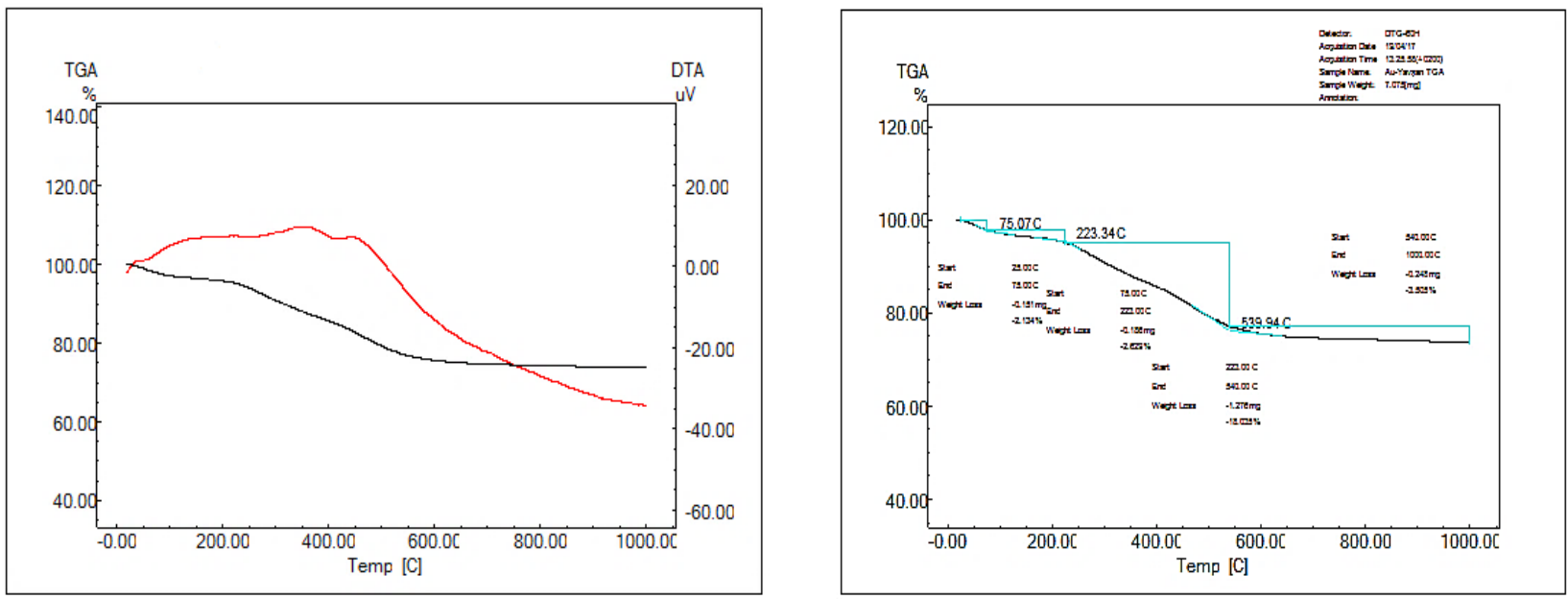

Figure 7. TGA-DTA results of AuNPs synthesized from Wormwood herb

\section{Antimicrobial activities of the AuNPs}

The nanoparticles obtained by green synthesis form reactive oxygen species (ROS), which negatively affect cell organelles and the structures in the cell have an affinity for these species (Sun et al., 2019). AuNPs adhere to the cell walls of bacteria and break down the cell membrane. They interact with phosphorus-containing structures, such as proteins and DNA, and negatively affect their function (Gopinath et al., 2016; Pirithiviraj et al., 2016). In this study, the inhibitory effects of the AuNPs obtained on Gram (+) S. aureus, ATCC 29213 and S. pyogenes ATTC 19615, Gram (-) E. coli ATCC25922 and P. aeruginosa ATCC 27853 strains and $C$. albicans yeast were examined. The obtained AuNPs were found to have inhibitory effects on Gram (+) S. aureus, ATCC 29213 and $S$. pyogenes ATTC 19615, Gram (-) E. coli ATCC25922 and P. aeruginosa ATCC 27853 strains and $C$. albicans ATTC 10231 yeast at concentrations of 0.250 and $0.125,0.125$ and $0.033,0.66 \mathrm{mg} \mathrm{mL}^{-1}$. The AuNPs were found to have a higher concentration effect on gram-positive bacteria due to the thick cell wall structure of these bacteria (Murugan et al., 2015). It has been reported that AuNPs synthesized with Anacardium occidentale extract had anti-microbial effects on gram-positive and negative bacteria (Anuradha et al., 2015). In a study regarding green synthesis, it was reported that a $5 \mathrm{mg} / \mathrm{L}$ concentration was insufficient for anti-fungal activity (Aravinthan et al., 2017). AuNPs synthesized with Allium saralicum have been reported to have a destructive effect on $2 \mathrm{mg} / \mathrm{ml}$ of $P$. aeruginosa and E. coli, $4 \mathrm{mg} / \mathrm{ml}$ of $S$. aureus and $8 \mathrm{mg} / \mathrm{ml}$ of $C$. albicans (Huang et al., 2007). When compared to other studies in the literature, it was determined that the AuNPs obtained in the present study had an inhibitory effect on low concentrations of $C$. albicans yeast and other gram (+) and gram (-) bacteria (Table 1).

Table 1. MIC values of synthesized gold nanoparticles (AuNPs) (mg mL ${ }^{-1}$ ) on $\mathrm{HAuCI}_{4}$ solution and, S. aureus, S. pyogenes (vancomycin), C. albicans (fluconazole) and P. aeruginosa, E. coli (colistin) microorganisms.

\begin{tabular}{|c|c|c|c|c|}
\hline & Tested Organisms & $\begin{array}{c}\text { AuNPs } \\
{\left[\mathrm{mg} \mathrm{mL}^{-1}\right]}\end{array}$ & $\begin{array}{c}\text { HAuCl4.3H2O } \\
{\left[\mathrm{mg} \mathrm{mL}^{-1}\right]}\end{array}$ & $\begin{array}{l}\text { Antibiotic } \\
{\left[\mathrm{mg} \mathrm{mL}^{-1}\right]}\end{array}$ \\
\hline \multirow{2}{*}{$\begin{array}{l}\text { Gram (+) bacterial } \\
\text { strains }\end{array}$} & S. aureus (ATCC 29213) & 0.250 & 0.5 & 2 \\
\hline & S. pyogenes (ATTC 19615) & 0.125 & 0.25 & 1 \\
\hline \multirow{2}{*}{$\begin{array}{l}\text { Gram (-) bacterial } \\
\text { strains }\end{array}$} & E. coli $(A T C C 25922)$ & 0.125 & 0.25 & 1 \\
\hline & P. aeruginosa ATCC 27853 & 0.033 & 0.1 & 1 \\
\hline Fungi & C. albicans (ATTC 10231) & 0.066 & 0.25 & 2 \\
\hline
\end{tabular}




\section{CONCLUSION}

The interest in ecologically friendly synthesis methods on a global scale is increasing day by day. With the increase in their usage, the synthesis of metallic nanoparticles is becoming more and more significant. AuNPs are used in many medical applications as anti-cancer, anti-microbial and antioxidant agents' due to their biocompatibility. In light of this information, in the present study, AuNPs were synthesized with the extract of the Artemisia absinthium plant using an eco-friendly, simple and cost-effective method. The nanoparticles showed a suppressive effect at low concentrations on the growth of microorganisms. By improving the synthesis steps, the AuNPs can be used in various medical applications and, due to their stability at high temperatures, they can also be used in different areas that require heat treatment.

\section{ACKNOWLEDGEMENT}

The authors are thankful to Mardin Artuklu University for providing all necessary research facilities to carry out this research.

\section{REFERENCES}

Aljabali AAA, Akkam Y, Al-Zoubi MS, Al-Batayneh KM, Al-Trad B, Abo-Alrob O, Alkilayn AM, Benamara M, Evans DJ, 2018. Synthesis of Gold Nanoparticles Using Leaf Extract of Ziziphus zizyphus and their Antimicrobial Activity. Nanomaterials-Basel 8(3): 1-15.

Ankamwar B, 2010. Biosynthesis of Gold Nanoparticles (Green-Gold) Using Leaf Extract of Terminalia catappa. Journal of Chemistry 7(4): 1334-1339.

Anuradha J, Abbasi T, Abbasi SA, 2015. An eco-friendly method of synthesizing gold nanoparticles using an otherwise worthless weed pistia (Pistia stratiotes L.). Journal of Advanced Research 6(5): 711-720.

Aravinthan A, Kamala-Kannan S, Govarthanan M, Kim JH, 2016. Accumulation of biosynthesized gold nanoparticles and its impact on various organs of Sprague Dawley rats: a systematic study. Toxicology Research 5: 1503-1511.

Balalakshmi C, Gopinath K, Govindarajan M, Lokesh R, Arumugam A, Alharbi NS, Kadaikunnan S, Khaled JM, Benelli G, 2017. Green Synthesis of Gold Nanoparticles Using a Cheap Sphaeranthus Indicus Extract: Impact on Plant Cells and the Aquatic Crustacean Artemia nauplii. Journal of Photochemistry and Photobiology B: Biology 173: 598-605.

Chaudhry N, 2018. Bio-inspired nanomaterials in agriculture and food: Current status, foreseen applications and challenges. Microbial Pathogenesis 123: 196-200.

Dubey SP, Lahtinen M, Sillanpää M, 2010. Green synthesis and characterizations of silver and gold nanoparticles using leaf extract of Rosa rugosa. Colloids and Surfaces A 364(1-3): 34-41.

Dwivedi AD, Gopal K, 2010. Biosynthesis of silver and gold nanoparticles using Chenopodium album leaf extract", Colloids and Surfaces A 369(1-3): 27-33.

Gharehyakheh S, Ahmeda A, Haddadi A, 2020. Effect of gold nanoparticles synthesized using the aqueous extract of Satureja hortensis leaf on enhancing the shelf life and removing Escherichia coli O157 : H7 and Listeria monocytogenes in minced camel' $s$ meat: The role of nanotechnology in the food industry. Applied Organometalic Chemistry 34(4): 1-11.

Gholami-Shabani M, Shams-Ghahfarokhi M, Gholami-Shabani Z, Akbarzadeh A, Riazi G, Ajdari S, Amani A, Razzaghi-Abyaneh M, 2015. Enzymatic Synthesis of Gold Nanoparticles Using Sulfite Reductase Purified from Escherichia Coli: A Green Eco-Friendly Approach. Process Biochemistry 50: 1076-1085.

Giljohann DA, Seferos DS, Daniel WL, Massich MD, Patel PC, Mirkin CA, 2010. Gold Nanoparticles for Biology and Medicine Angewandte. Angewandte Chemie International Edition in English 49(19): 32803294. 
Gopinath K, Kumaraguru S, Bhakyaraj K, Mohan S, Venkatesh KS, Esakkirajan M, Kaleeswarran P, Alharbi NS, Kadaikunnan S, Govindarajan M, Benelli G, Arumugam A, 2016. Green synthesis of silver, gold and silver/gold bimetallic nanoparticles using the Gloriosa superba leaf extract and their antibacterial and antibiofilm activities. Microbial Pathogenesis 101: 1-11.

Gunalan S, Rajeshwari S, Venckatesh R, 2012. Green Synthesized ZnO Nanoparticles against Bacterial and Fungal Pathogens. Progress in Natural Science: Materials International 22: 693-700.

Huang H, Yang X, 2004. Synthesis of polysaccharide-stabilized gold and silver nanoparticles : a green method. Carbohydrate Research 339: 2627-2631.

Huang J, Li Q, Sun D, Lu Y, Su Y, Yang X, Wang H, Wang Y, Shao W, He N, Hong J, Chen C, 2007. Biosynthesis of silver and gold nanoparticles by novel sundried Cinnamomum camphora leaf. Nanotechnology 18(10): 105104.

Jacob R, Harikrishnan GN, Isac J, 2015. Structural and Morphological Studies of Nanocrystalline Ceramic $\mathrm{BaSr}_{0-9} \mathrm{Fe}_{0-1} \mathrm{TiO}_{4}$. International Letters of Chemistry, Physics and Astronomy 41: 100-117.

Jeyaraj M, Gurunathan S, Qasim M, Kang MH, Kim JH, 2019. A Comprehensive Review on the Synthesis, Characterization, and Biomedical Application of Platinum Nanoparticles. Nanomaterials 9(12): 1-41.

Kanchi S, Kumar G, Lo AY, Tseng CM, Chen SK, Lin CY, Chin TS, 2018. Exploitation of de-oiled jatropha waste for gold nanoparticles synthesis: A green approach. Arabian Journal of Chemistry 11(2): 247-255.

Khan SA, Shahid S, Bashir W, Kanwal S, Iqbal A, 2017. Synthesis, characterization and evaluation of biological activities of manganese doped zinc oxide nanoparticles. Tropical Journal of Pharmaceutical Research 16: 2331-2339.

Khan SA, Shahid S, Lee CS, 2020. Green Synthesis of Gold and Silver Nanoparticles Using Leaf Extract of Clerodendrum inerme; Characterization, Antimicrobial, and Antioxidant Activities. Biomolecules 10: 835.

Khan SA, Shaid S, Shahid B, Fatima U, Abbasi SA, 2020. Green Synthesis of MnO Nanoparticles Using Abutilon indicum Leaf Extract for Biological, Photocatalytic, and Adsorption Activities. Biomolecules 10: 785 .

Khoshnamvand M, Ashtiani S, Huo C, Saeb SP, Liu J, 2019. Use of Alcea rosea leaf extract for biomimetic synthesis of gold nanoparticles with innate free radical scavenging and catalytic activities. Journal of Molecular Structure 1179: 749-755.

Kobashigawa JM, Robles CA, Martínez Ricci ML, Carmarán CC, 2018. Influence of strong bases on the synthesis of silver nanoparticles (AgNPs) using the ligninolytic fungi Trametes trogii, Saudi Journal of Biological Sciences 4-10.

Kumar KP, Paul W, Sharma CP, 2013. Green synthesis of gold nanoparticles with Zingiber officinale extract: Characterization and blood compatibility. Process Biochemistry 46(10): 2007-2013.

Kumar P, Saravana M, Vimalin J, Malathi J, Ignacimuthu S, 2018. Anticancer Effects of One-Pot Synthesized Biogenic Gold Nanoparticles (Mc-AuNps) against Laryngeal Carcinoma. Journal of Drug Delivery Science and Technology 44: 118-128.

McFarland J, 1907. Nephelometer: an instrument for media used for estimating the number of bacteria in suspensions used for calculating the opsonic index and for vaccines. Journal of the American Medical Association 14: 1176-1178.

Menon S, Rajeshkumar S, Venkat-Kumar S, 2017. A review on biogenic synthesis of gold nanoparticles, characterization, and its applications. Resource-Efficient Technologies 3(4): 516-527.

Mubarakali D, Thajuddin N, Jeganathan K, Gunasekaran M, 2011. Biointerfaces Plant extract mediated synthesis of silver and gold nanoparticles and its antibacterial activity against clinically isolated pathogens. Colloids and Surface B 85(2): 360-365.

Murphin Kumar PS, Mubarak Ali D, Saratale RG, Saratale GD, Pugazhendhi A, Gopalakrishnan K, Thajuddin N, 2017. Synthesis of nano-cuboidal gold particles for effective antimicrobial property against clinical human pathogens. Microbial Pathogenesis 113: 68-73. 
Murugan K, Benelli G, Panneerselvam C, Subramaniam J, Jeyalalitha T, Dinesh D, Nicoletti M, Hwang JS, Suresh U, Madhiyazhagan P, 2015. Cymbopogon citratus-synthesized gold nanoparticles boost the predation efficiency of copepod Mesocyclops aspericornis against malaria and dengue mosquitoes. Experinmental Parasitology 153: 129-138.

Mythili R, Selvankumar T, Srinivasan P, Sengottaiyan A, Sabastinraj J, Ameen F, Al-Sabri A, Kamala-Kannan S, Govarthanan M, Kime H, 2018. Biogenic synthesis, characterization and antibacterial activity of gold nanoparticles synthesised from vegetable waste. Journal of Molecular Liquids 262: 318-321.

Oueslati MH, Ben-Tahar L, Harrath AH, 2020. Synthesis of ultra-small gold nanoparticles by polyphenol extracted from Salvia officinalis and efficiency for catalytic reduction of p-nitrophenol and methylene blue. Green Chemistry Letters and Reviews 13(1): 18-26.

Patra JK, Gitishree D, Baek KH, 2016. Phyto-Mediated Biosynthesis of Silver Nanoparticles Using the Rind Extract of Watermelon (Citrullus lanatus) under Photo-Catalyzed Condition and Investigation of Its Antibacterial, Anticandidal and Antioxidant Efficacy. Journal of Photochemistry and Photobiology B 161: 200-210.

Philip D, 2010. Green synthesis of gold and silver nanoparticles using Hibiscus rosa sinensis. Physica E: Lowdimensional Systems and Nanostructures 42(5): 1417-1424.

Piruthiviraj P, Anita M, Poornimau P, 2016. Gold Nanoparticles Synthesized by Brassica oleracea (Broccoli) Acting as Antimicrobial Agents against Human Pathogenic Bacteria and Fungi. Applied Nanoscience 6: 467-473.

Rajathi FAA, Arumugam R, Saravanan S, Anantharaman P, 2014. Phyto fabrication of gold nanoparticles assisted by leaves of Suaeda monoica and its free radical scavenging property. Journal of Photochemistry and Photobiology B 135: 75e80.

Santhosh AS, Sandeep S, Kumara Swamy N, 2019. Green synthesis of nano silver from Euphorbia geniculata leaf extract: Investigations on catalytic degradation of methyl orange dye and optical sensing of $\mathrm{Hg} 2+$. Surface and Interface Analysis 14: 50-54.

Shahid S, Fatima U, Sajjad R, Khan SA, 2019. Bioinspired Nanotheranostic Agent: Zinc Oxide; Green Synthesis and Biomedical Potential. Digest Journal of Nanomaterials and Biostructures 14(4): 1023-1031.

Shaid S, Khan SA, Ahmad W, Fatima U, Knawal S, 2018. Size-dependent Bacterial Growth Inhibition and Antibacterial Activity of Ag-doped $\mathrm{ZnO}$ Nanoparticles under Different Atmospheric Conditions. Indian Journal of Pharmaceutical Sciences 80(1): 173-180.

Shao Y, Wu C, Wu T, Yuan C, Chen S, Ding T, Ye X, Hu Y, 2018. Green synthesis of sodium alginate-silver nanoparticles and their antibacterial activity. International Journal of Biological Macromolecules 111: 1281-1292.

Sun B, Hu N, Han L, Pi Y, Gao Y, Chen K, 2019. "Anticancer activity of green synthesised gold nanoparticles from Marsdenia tenacissima inhibits A549 cell proliferation through the apoptotic pathway, Artif. Artificial Cells, Nanomedicine, and Biotechnology 47(1): 4012-4019.

Teimuri-mofrad R, Hadi R, Tahmasebi B, Farhoudian S, 2017. Green synthesis of gold nanoparticles using plant extract. Nanochemistry Research 2(1): 8-19.

Zha J, Dong C, Wang X, Zhang X, Xiao X, Yang X, 2017. Green synthesis and characterization of monodisperse gold nanoparticles using Ginkgo Biloba leaf extract. Optik (Stuttg). 144: 511-521. 